\title{
Pollution Characteristics of Polycyclic Aromatic Hydrocarbons in Unsaturated Zone of the Different Workshops at a Large Iron and Steel Industrial Site of Beijing, China
}

\author{
Xiangshuai Meng ${ }^{1,2 *}$, Honghan $\mathrm{Chen}^{1}$, Mengmeng $\mathrm{Wu}^{1}$ \\ ${ }^{1}$ School of Water Resources and Environment, China University of Geosciences, Beijing 100083, PR China \\ ${ }^{2}$ Capital Engineering \& Research Incorporation Ltd., Beijing 100053, PR China
}

Received: 1 January 2020

Accepted: 12 June 2020

\begin{abstract}
The distribution, compositions, sources and ecological risk for polycyclic aromatic hydrocarbons (PAHs) in industrial fields at a large iron and steel enterprise are discussed. Maximum $\Sigma$ PAHs concentrations in soils of different workshops ranged from 17.50 to $11266.80 \mathrm{mg} \cdot \mathrm{kg}^{-1}$. The $\Sigma$ PAHs concentrations of the field could classify three categories due to different discharge ways and combustion condition: $>1000 \mathrm{mg} \cdot \mathrm{kg}^{-1}, 10-1000 \mathrm{mg} \cdot \mathrm{kg}^{-1},<10 \mathrm{mg} \cdot \mathrm{kg}^{-1}$. The spatial distribution of BaP concentration in the coking topsoil was affected by fugitive emissions significantly. Peak values of PAHs occurred in silt lens in 20-30 m depth indicated that pore size radius and conductivity of unsaturated zone played a critical role in the vertical distribution. The strong linear correlation between the multiple organic contaminants indicated that benzene series worked as co-solvents and competitors in unsaturated zone to promote PAHs migration. Nap and Phe were the most abundant compounds in the coking and coal stockyard sites, while Fla, BbF, Pyr, Phe and Chry predominated in other workshops affected by different sources in which coal combustion was the primary source of PAHs. The calculated TEQ of the coking site was found highest and $\mathrm{BaP}$ was the most concerning pollutant of the field since the values accounted for $57.8-64.4 \%$ of total PAHs in the different workshops.
\end{abstract}

Keywords: polycyclic aromatic hydrocarbons; iron and steel enterprises, unsaturated zone, distribution and compositions, sources

\section{Introduction}

Polycyclic aromatic hydrocarbons (PAHs) have carcinogenic, teratogenic and mutagenic characteristics

*e-mail: mengxiangshuai@ceri.com.cn which pose a significant risk to human health and cause a major environmental concern [1-2]. PAHs released into the environment will generally enter into the soil due to their lipophilic and hydrophobic characteristic. The abandoned iron and steel sites in the urban areas sometimes are severely polluted by PAHs which are also precious land resources used for real estates, parks 
and entertainment facilities. Understanding pollution characteristics of PAHs in the soil is the premise of soil remediation and land reuse.

The iron and steel industry is an important source of PAHs in China, contributing 15.2\% (coke production and iron industry) of national total PAH emissions [3], which is larger than any other countries. Several studies have investigated PAH concentrations and compositions in different phases by stack emissions [4-5] and fugitive emissions [6-7]. Atmospheric PAHs continuously deposit to the soil via dry and wet deposition and soil becomes the most critical sink for PAHs in the environment [8-9]. Due to their high affinity for soil organic matter, PAHs derived from combustion are mainly restricted to the top layer of the soil [10]. Therefore, numerous studies have been conducted to investigate PAHs pollution of topsoil at the coking or iron industrial areas [11-13]. Limited studies have been done regarding soil pollution caused by accidental leakage, dumping, spillage and buried wastes [1415], which might result in deeper distribution and higher concentrations. Unsaturated zone frequently has heterogeneous properties with increasing depth leading to complicated vertical distribution characteristics of PAHs, such field-contaminated cases were rarely reported [16].

Iron and steel enterprises consist of stockyard, coking, sintering, iron making, steel making, steel rolling and other workshops. Due to high levels of PAHs in soil, the sites of coking or manufacturedgas plants have been investigated worldwide [1719], but rare studies focus on the whole enterprises or other workshops. Actually, each workshop might have distinctive pollution characteristics in soil due to their unique sources. Understanding PAH levels, compositions, distribution and ecological risk affected by different processes in unsaturated zone could offer beneficial reference for site investigation and risk control for iron and steel industry.

The objectives of the present study were: (1) to explore levels and spatial distribution of PAHs and related controlling factors in surface soil of the different workshops, (2) to understand vertical distribution and migration characteristic of PAHs under heterogeneous conditions in deep unsaturated zone and (3) to determine PAH compositions, sources and ecological risk in soils of the different workshops.

\section{Materials and Methods}

\section{Study Areas and Sample Collection}

The iron and steel enterprise was built in 1919, and shut down in 2010, covering an area of about $1.42 \mathrm{~km}^{2}$. Six workshops were comprised of the enterprise of which the coking site was divided into two parts, the west area mainly was used for coke production while the east area for tar refining and chemical production.
The field was located at alluvial fan foreland, the stratum can be generally divided into backfill, silty clay, gravel and pebble whose thickness reach to more than $40 \mathrm{~m}$. Groundwater depth of the site occurring in the gravel and pebble layer was greater than $30 \mathrm{~m}$.

71 soil samples were collected at different depths and tested from six sites including the coking plant (CP), the coal stockyard (CS), the sintering plant (SP), the boiler plant (BP), the iron making plant (IM) and the steel making plant (SM) in January 2014. Sample locations were designed to be in surrounding areas of open yards, wastewater pools, oil tanks where soils were potentially influenced by PAHs. The locations of the sampling sites are shown in Fig. 1. According to lithology, color, odor, photoionization detector readings, soil sampling depth of different workshops varied from 0.2 to $42.0 \mathrm{~m}$ combined with preliminary investigation results that pollution of deep unsaturated zone mainly occurred in the CP site. C1-C7, B5, G2 sites collected soil samples along the profile from each borehole by drilling, the number of samples ranged from 3 to 7 , and specific depths of the profiles were shown as Fig. 3. Other locations just collected one surface sample within $1 \mathrm{~m}$ depth using stainless steel shovels. Soil samples were taken with $250 \mathrm{~mL}$ transparent glass bottles, sealed with PTFE cap and stored at $4^{\circ} \mathrm{C}$ before transporting to the laboratory.

\section{Sample Extraction and Analysis}

Soil samples $(10 \mathrm{~g})$ were added with anhydrous $\mathrm{Na}_{2} \mathrm{SO}_{4}$ (heated at $400^{\circ} \mathrm{C}$ for $4 \mathrm{~h}$ ) and copper powder (activated with dilute hydrochloric acid, distilled water, methanol, and n-hexane), then samples were Soxhletextracted for $18 \mathrm{~h}$ with $100 \mathrm{~mL}$ acetone/ hexane solvent $(\mathrm{v} / \mathrm{v}=1: 1)$. The extracts were then

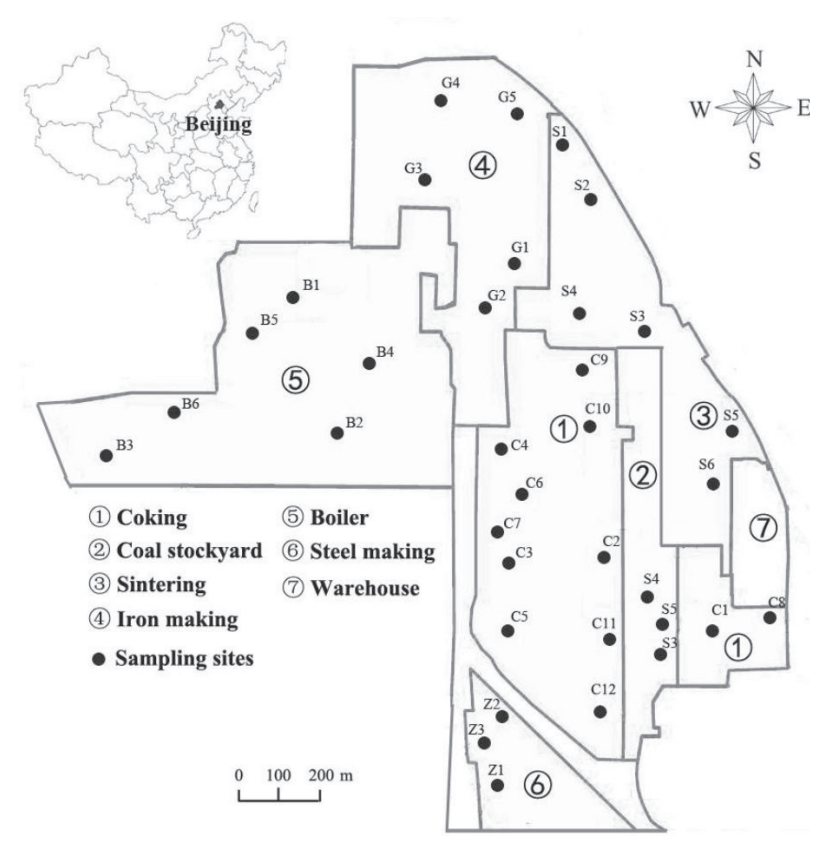

Fig. 1. The locations of soil samples in the different workshops. 
concentrated to approximately $2 \mathrm{~mL}$ by evaporation in the gentle nitrogen stream, followed by purification on a $3-\mathrm{cm}$ activated silica, 3-cm neutral alumina and 2-cm anhydrous $\mathrm{Na}_{2} \mathrm{SO}_{4}$ column with $25 \mathrm{~mL}$ of hexane/dichloromethane $(\mathrm{v} / \mathrm{v}=1: 1)$ mixture. Next, the collected PAH fraction was vacuum-evaporated and solvent-exchanged to $\mathrm{n}$-hexane, and then concentrated to $1 \mathrm{~mL}$ under a gentle stream of nitrogen.

16 USEPA priority PAHs were analyzed, including naphthalene (Nap), acenaphthene (Ace), acenaphthylene (Acy), fluorene (Flu), phenanthrene (Phe), anthracene (Ant), fluoranthene (Fla), pyrene (Pyr), benzo(a) anthracene (BaA), chrysene (Chry), benzo(b)fluoranthene $(\mathrm{BbF})$, benzo(k)fluoranthene $(\mathrm{BkF})$, benzo(a)pyrene (BaP), indeno(1,2,3-cd)pyrene (InP), dibenzo(a,h)anthracene (DahA), and benzo(g,h,i) perylene (BghiP). PAHs composition analysis was performed on a Shimadzu GCMS-QP2010 Plus with a DB-5 capillary column $(30 \times 0.25 \mathrm{~mm}$ diameter, $1 \mu \mathrm{m}$ film thickness). Helium was used as the carrier gas constant flowing at $1.0 \mathrm{~mL} / \mathrm{min}$. Injection mode: splitless; injections were made at a volume of $1.0 \mu \mathrm{L}$. Injector, ion source, transfer line and quadrupole temperatures were set at 280, 230, 280 and $150^{\circ} \mathrm{C}$, respectively. The $\mathrm{GC}$ oven temperature was programmed as follows: held at $35^{\circ} \mathrm{C}$ for $2 \mathrm{~min}$, increased to $150^{\circ} \mathrm{C}$ at rate of $15^{\circ} \mathrm{C} / \mathrm{min}$ and held for
$5 \mathrm{~min}$, then raised to $290^{\circ} \mathrm{C}$ at rate of $3^{\circ} \mathrm{C} / \mathrm{min}$ and held for $5 \mathrm{~min}$. The electron impact energy was set at $70 \mathrm{eV}$.

\section{Quality Assurance and Quality Control}

All analytical procedures were monitored with strict quality assurance and quality control measures. Before the onset of the sampling and analysis program, PAHs recovery studies were undertaken to demonstrate the availability of the method. One quality control sample was set for every 10 samples, and the error of each parallel sample was less than $40 \%$. The recovery rates of substitute were controlled between $60 \%$ and $120 \%$, which was in line with the quality control requirements of the laboratory.

\section{Results and Discussion}

Distribution and Levels of PAHs

\section{Spatial Distribution of $\Sigma P A H$ S Concentrations in Different Workshops}

Maximum $\Sigma$ PAHs (the total 16 priority PAHs) concentrations in soils of different workshops ranged from 17.50 to $11266.80 \mathrm{mg} \cdot \mathrm{kg}^{-1}$. PAHs levels in soils

Table 1. Descriptive statistics of PAHs in surface soils of the workshops $\left(\mathrm{mg} \cdot \mathrm{kg}^{-1}\right)$.

\begin{tabular}{|c|c|c|c|c|c|c|c|c|c|c|c|}
\hline Workshops & $\mathrm{CP}$ & $\mathrm{CS}$ & SP & $\mathrm{BP}$ & IM & SM & \multicolumn{5}{|c|}{ All the workshops } \\
\hline PAHs & \multicolumn{6}{|c|}{ Mean } & Min & Max & Mean & Med & $\mathrm{CV}(\%)$ \\
\hline Nap & 348.81 & 1.37 & 0.23 & 1.50 & 0.08 & 0.14 & N.D. & 3300.00 & 168.51 & 0.70 & 349.01 \\
\hline Ace & 78.64 & 0.28 & 0.05 & 1.41 & 0.38 & 0.16 & N.D. & 643.00 & 38.20 & 0.55 & 278.11 \\
\hline Acy & 53.77 & 0.23 & 0.05 & 1.53 & 0.17 & 0.11 & N.D. & 837.00 & 26.19 & 0.25 & 472.20 \\
\hline Flu & 111.57 & 0.32 & 0.05 & 1.97 & 0.30 & 0.16 & N.D. & 818.00 & 54.15 & 0.51 & 263.27 \\
\hline Phe & 236.00 & 2.11 & 0.83 & 8.18 & 2.35 & 1.93 & N.D. & 1730.00 & 115.62 & 3.85 & 277.74 \\
\hline Ant & 72.83 & 0.37 & 0.25 & 2.85 & 1.13 & 0.43 & N.D. & 596.00 & 35.76 & 1.40 & 273.44 \\
\hline Fla & 147.98 & 0.91 & 1.34 & 12.35 & 7.04 & 4.52 & N.D. & 1310.00 & 74.58 & 8.70 & 275.68 \\
\hline Pyr & 103.57 & 0.68 & 1.33 & 10.93 & 5.62 & 3.64 & N.D. & 866.00 & 52.70 & 7.11 & 259.10 \\
\hline $\mathrm{BaA}$ & 52.69 & 0.51 & 0.97 & 5.21 & 3.59 & 2.31 & N.D. & 488.00 & 26.94 & 4.93 & 275.57 \\
\hline Chry & 51.58 & 0.62 & 1.22 & 4.79 & 4.48 & 2.59 & N.D. & 432.00 & 26.53 & 4.61 & 252.50 \\
\hline $\mathrm{BbF}$ & 58.62 & 0.70 & 1.80 & 7.83 & 6.43 & 2.78 & N.D. & 498.00 & 30.72 & 7.43 & 254.16 \\
\hline $\mathrm{BkF}$ & 18.81 & 0.22 & 0.60 & 2.30 & 2.59 & 1.84 & N.D. & 135.00 & 9.96 & 2.66 & 230.50 \\
\hline $\mathrm{BaP}$ & 45.38 & 0.42 & 1.12 & 4.63 & 3.05 & 2.01 & N.D. & 413.00 & 23.26 & 3.20 & 277.85 \\
\hline InP & 29.99 & 0.21 & 0.48 & 2.94 & 1.85 & 1.97 & N.D. & 314.00 & 15.33 & 1.98 & 310.60 \\
\hline DahA & 8.49 & 0.10 & 0.21 & 0.91 & 0.66 & 0.37 & N.D. & 84.80 & 4.37 & 0.55 & 295.72 \\
\hline BghiP & 30.72 & 0.26 & 0.73 & 3.34 & 1.98 & 1.72 & N.D. & 247.00 & 15.78 & 2.62 & 268.52 \\
\hline$\Sigma_{16}$ PAHs & 1449.45 & 9.29 & 11.25 & 72.67 & 41.69 & 26.69 & N.D. & 11266.80 & 718.61 & 54.37 & 264.95 \\
\hline
\end{tabular}

N.D.: Not Detected 
even were several orders of magnitude higher than that of the previous investigation $\left(1.0-1.5 \mathrm{mg} \cdot \mathrm{kg}^{-1}\right)$ of the area [20]. The variability illustrated in the soils reflected the difficulty of accurately characterizing PAH distributions in industrial soils due to limitations of field sampling. Descriptive statistics of PAHs in surface soils $(0-5 \mathrm{~m})$ of the different workshops was showed in Table 1. PAHs pollution was most serious in the $\mathrm{CP}$ site and the average concentration of $\Sigma$ PAHs in surface soil could reach $1449.45 \mathrm{mg} \cdot \mathrm{kg}^{-1}$, 156.02 times higher than the coal stockyard soils which had the lowest content compared with other workshops.The coefficient of variation (CV) of individual PAHs exceeded $230 \%$, and it also indicated a strong heterogenic spatial distribution of PAHs in the field. According to soil contamination classification system from the previous study [21], all the samples were heavily contaminated $\left(\Sigma_{16} \mathrm{PAHs}>1000 \mathrm{ng} / \mathrm{g}\right)$ except for $\mathrm{G} 2$

The field could classify three categories based on the average $\Sigma$ PAHs concentrations as follows: $>1000 \mathrm{mg} \cdot \mathrm{kg}^{-1}$ (CP), $10-1000 \mathrm{mg} \cdot \mathrm{kg}^{-1}$ (BP, IM, SM, $\mathrm{SP}),<10 \mathrm{mg} \cdot \mathrm{kg}^{-1}(\mathrm{CS})$. The different degrees of PAHs pollution were closely related with distinct discharge ways (dry/wet deposition, solid wastes leaching, leakage of wastewater pools and oil tanks, etc.), combustion condition and even burning stages of coal in the workshops. In the CP, the processes in the dry distillation of bituminous coals which have the highest concentration of 16-PAHs than lignite and anthracite [22] could yield PAHs emissions at a large scale and are the major contributors to the iron and steel industry. Coking wastewaters, oils and solid wastes produced during deep processing of tar and gas purification also contain high concentrations of PAHs. The coking sites are susceptible to all the pathways due to different phases of PAHs, therefore the ground surface in the vicinity of coke ovens or coke byproducts plants often is highly contaminated [23]. In the BP, IM, SM and SP, coals act as fuels or raw materials during manufacturing, sources of PAHs in such industrial fields mainly result from combustion, through dry/wet deposition of coal soot, unburned coal, charcoal and fly ash. In the CS site, leaching of pulverized coal is the major way leading to soil pollution. PAH concentrations in coals is lower than soot-like materials typically [24], and the coal particles also have a very large sorption capacity resulting in a slow or very slow desorption [25-26]. Hence, the CS soil was just lighter in PAHs levels compared with other workshops. Despite of their different levels, PAHs pollution was strongly associated with utilization of metallurgical coal in the workshops.

In addition, a comparison of PAHs concentrations in soils from different areas worldwide is given in Table 2, where it can be seen that the mean concentration of $\Sigma$ PAHs in the soil was much higher than other industrial soils, especially for the CP site. The results indicate that solid wastes leaching, leakage of wastewater pools and oil tanks of the CP could cause most severe pollution of soil since the other industrial areas were mainly contaminated by dry/wet deposition of soot-like materials.

\section{Spatial Distribution in Surface Soils of the Different Workshops Affected by Wind Direction}

Atmospheric pollutants are most commonly compared with other discharge ways in industrial activity, and wind direction always plays an important role in controlling spatial distribution and levels of PAHs in surface soil of iron and steel field [27, 30]. In order to understand the characteristic of PAHs distribution affected by winds, 80 samples from surface soil (0-1 m) including the other samples $(n=42)$ which were collected spanning from 2014 to 2019 were analyzed at the field. BaP was chosen as the indicatory PAHs which is less volatile and degradable than LM-PAHs (2, 3-ring) and MM-PAHs (4-ring). The prevailing wind directions are northeaster or southwester changing with seasons and the spatial distributions of $\mathrm{BaP}$ concentration in the two areas of the CP was affected by wind direction obviously (Fig. 2). The reason may be the low height of the chimneys (comparing e.g. with boiler or blast furnace chimneys) and the large amount of fugitive emissions of coarse grains arising in such processes as battery filling, coke discharging and quenching felt out closer to the source [13]. In refining workshops of the $\mathrm{CP}$, the storage tanks containing oils or wastewater also could release or leak a great deal of organic gases. The maximum discharge heights of such sources are lower than $20 \mathrm{~m}$. While the combustion of coal is fully under oxygen-rich condition and chimney heights are more than $100 \mathrm{~m}$ in other manufacturing workshops, a weak

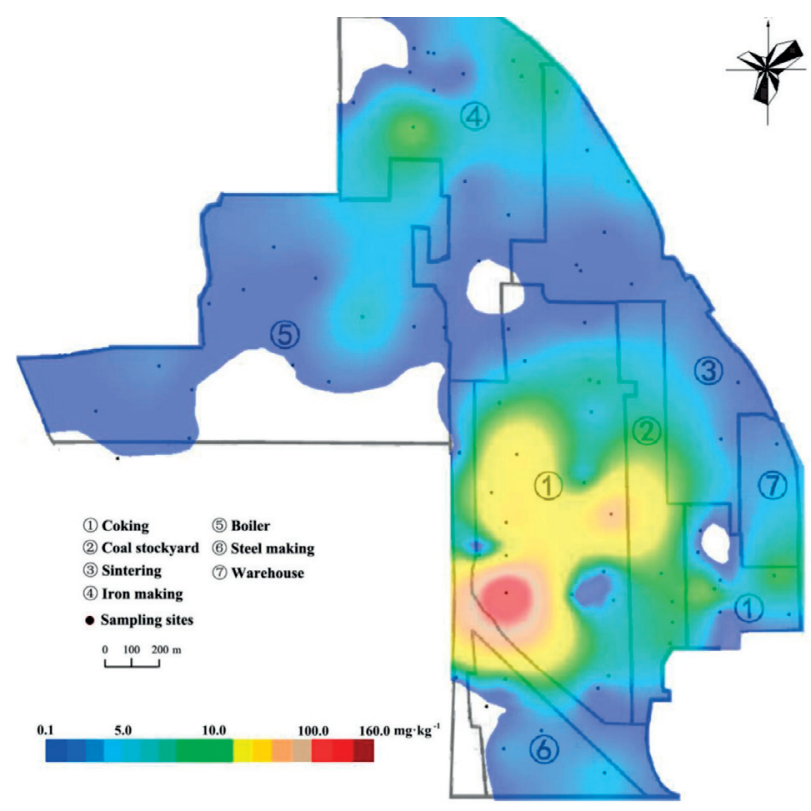

Fig. 2. Spatial distributions of $\mathrm{BaP}$ concentration in surface soil $(0-1 \mathrm{~m})$ of the field 
Table 2. Concentration comparison of $\Sigma_{16} \mathrm{PAHs}$ in soils from different industrial soils.

\begin{tabular}{|c|c|c|c|c|c|}
\hline \multirow{2}{*}{ Location } & \multirow{2}{*}{ Soil Types } & \multicolumn{2}{|c|}{ Concentration $\left(\mathrm{mg} \cdot \mathrm{kg}^{-1}\right)$} & \multirow{2}{*}{ References } \\
\cline { 3 - 6 } & & Min & Max & Mean & \\
\hline Beijing, China & The Iron and Steel Soil & N.D. & 11266.80 & 718.60 & This Study \\
\hline Loess Plateau, China & Petroleum-Contaminated Soil & 1.01 & 18.07 & 5.50 & Wang et al. [9] \\
\hline Opole, Poland & $\begin{array}{c}\text { Coking and Metallurgical } \\
\text { Industrial Soil }\end{array}$ & 1.56 & 101.30 & 18.84 & Rachwał et al. [13] \\
\hline Shanxi, China & Industrial Soil & 0.79 & 25.04 & 8.35 & Jiao et al. [27] \\
\hline Ulsan, Korea & Multi-Industrial Soil & 0.065 & 12.00 & 0.96 & Kwon \& Choi [28] \\
\hline Iskenderun Region, Turkey & Industrial Soil & 0.89 & 43.48 & 3.42 & Falay et al. [29] \\
\hline
\end{tabular}

N.D.: Not Detected

relationship was showed between BaP concentration and wind direction. Spatial distribution of PAHs affected by wind direction was possibly associated with pyrolytic condition and discharge ways. Furthermore, artificial disturbance and other sources such as solid wastes (coal ash, tar slag, etc.) of the field also have interfered in the spatial distribution.

\section{Vertical Distribution of $\Sigma P A H S$ Concentrations in the Profiles}

9 profiles were analyzed for determining vertical distribution of $\Sigma$ PAHs concentrations of unsaturated zone (Fig. 3). The highest $\Sigma$ PAHs concentrations mainly occurred in 2-5 $\mathrm{m}$ depth. The possible reasons are as follows: (1) construction activities including excavation, translocation and backfilling caused surface pollutants to enter into deep soil. For example, $\Sigma$ PAHs concentrations at G2 and B5 increased with depth, coal particles and soot-like materials were observed at deep soils of the two profiles, (2) PAHs in surface soil are exposed to the atmosphere directly and easily dissipate affected by photolysis, volatilization, biodegradation

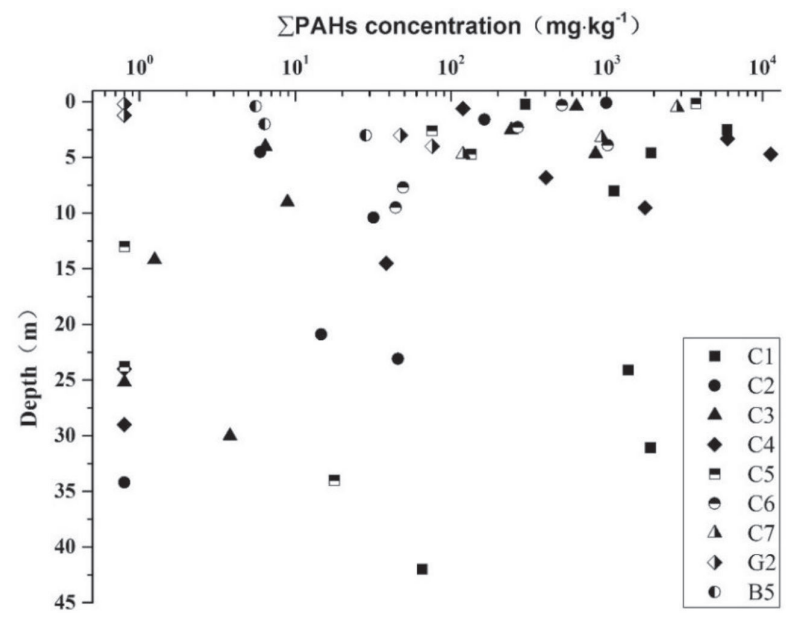

Fig. 3. Vertical distribution of $\Sigma \mathrm{PAHs}$ concentrations in unsaturated zone. and leaching [9], causing reduction of concentrations in surface layer and (3) bottom depths of wastewater pools, oil tanks and their pipelines of the CP are mainly higher than $2 \mathrm{~m}$, seepage could lead to heavy pollution blow the bottom of such devices [17].

$\mathrm{PAH}$ concentrations descended with increasing depth between 5 and $20 \mathrm{~m}$ depth underground, whereas peak values occurred in 20-30 m depth of unsaturated zone again where sand or silt lens appeared in the gravel and pebble layer. The stratigraphy of the field exerted an important effect on how contaminants migrate and distribute in the subsurface. Low molecular weight PAHs (essentially up to three cycles) transports in dissolved form, while PAHs with higher molecular weights associates with colloids or particulates [31]. The particle-associated PAH could account for up to $42 \%$ of the total exported PAH leached by water flow in NAPL-contaminated gravelly soil [32]. Pore throat size of unsaturated zone is one of the most important factors influencing PAH mobility of particulates [33]. The gravel and pebble layer of the field generally has larger pore size radius and greater conductivity to make the pollutants move through easier than the sand or silt layer, it also has relatively lower organic matter content and surface to volume ratio which plays an important role in adsorbing PAHs. The vertical distribution of PAHs of different boreholes with more than $30 \mathrm{~m}$ depth (Fig. 4) suggested the gravel and pebble layer became the preferential flow paths for PAHs, while interbedded sand or silt lens whose thickness range from 0.5 to $3 \mathrm{~m}$ existed as pooling layers and penetrating barriers due to its lower conductivity and minor pore size. However, it was not always the fine lens affected by higher levels in all profiles. PAHs was no detected within sand lens at a depth of $13.0 \mathrm{~m}$ and $23.0 \mathrm{~m}$ respectively, but reached $17.85 \mathrm{mg} \cdot \mathrm{kg}^{-1}$ at a depth of $34 \mathrm{~m}$ in the gravel layer at C4. Lateral spreading of organic contaminant has been observed at top interfaces of the lens in heterogeneous soil [34]. Sources could pollute adjacent area in horizontal direction by lateral and vertical transport without influencing upper soil in heterogeneous condition. It deduced that sources of PAHs might 

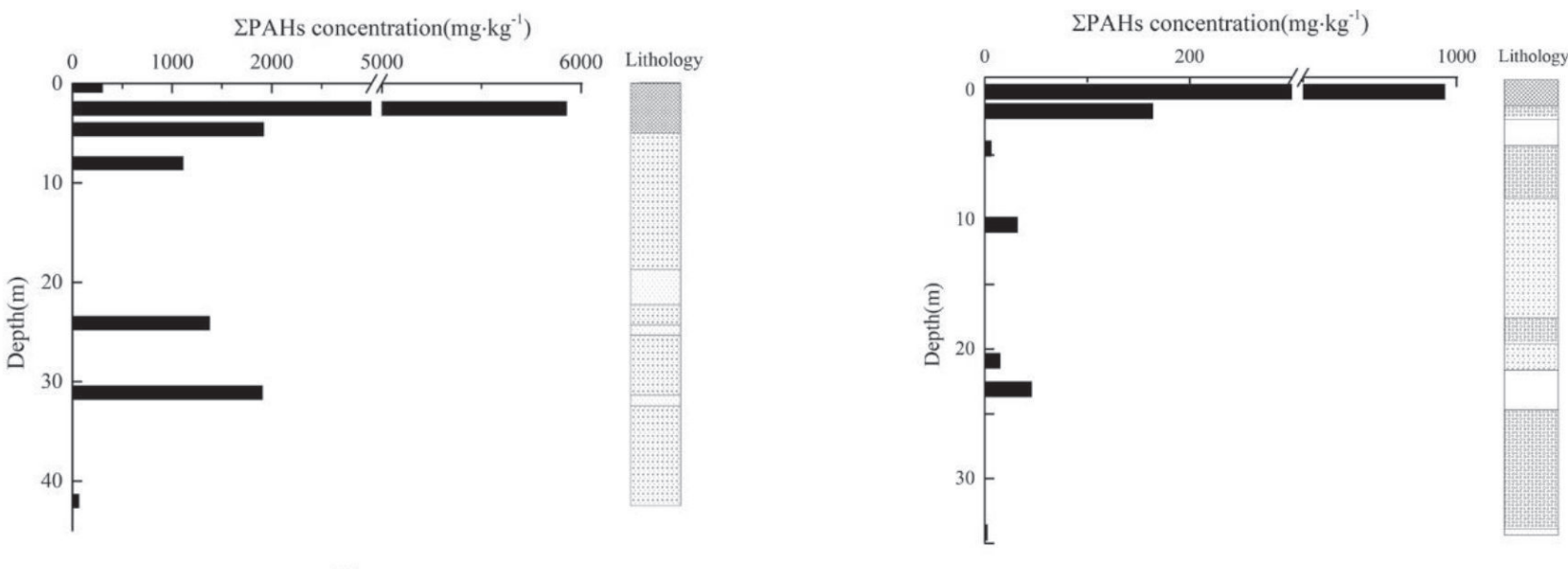

C1
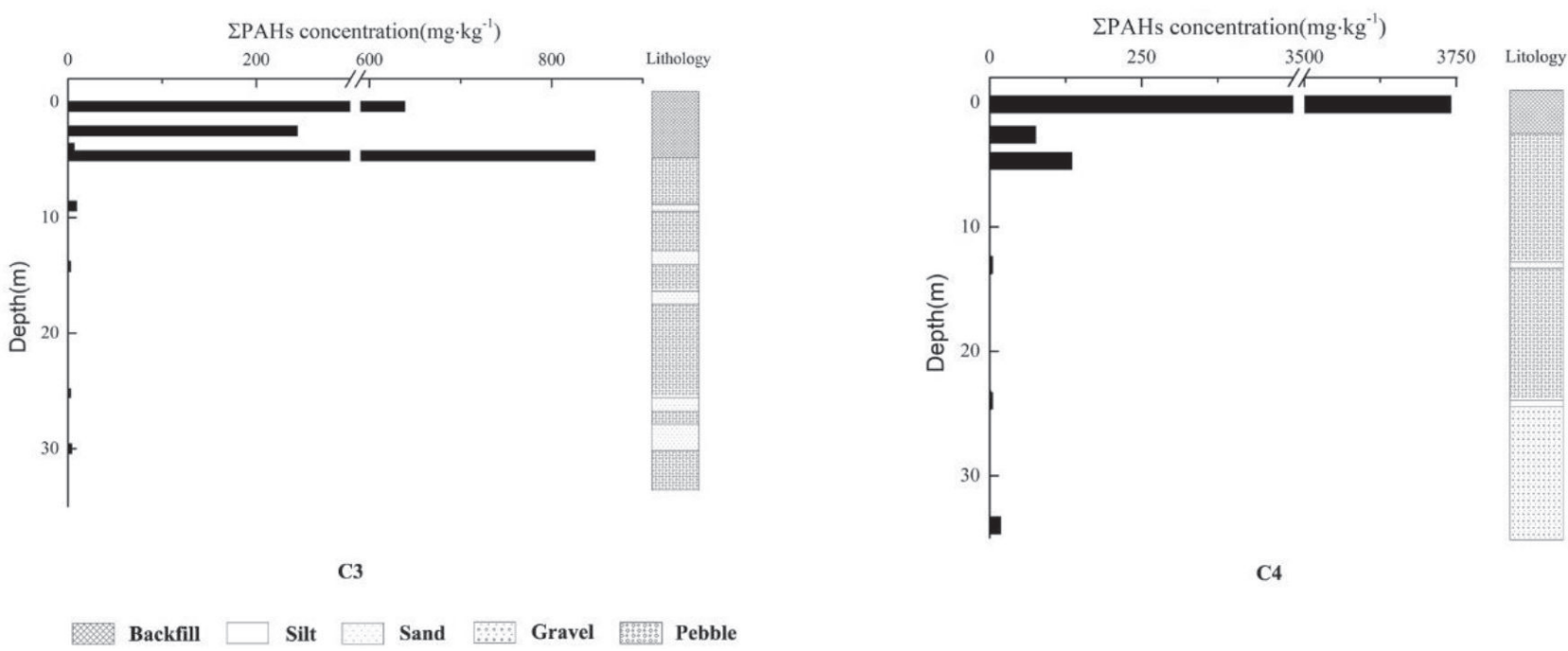

C4

Fig. 4. The relationship between $\Sigma$ PAHs concentrations and lithology in deep boreholes.

come from lateral transport, not vertical infiltration directly.

\section{The Possible Causes of Deep Unsaturated Zone Pollution}

The maximum value and migration depth of PAHs in unsaturated zone all occurred in the CP site. HM-PAHs (5, 6-ring) even reached $2.52 \mathrm{mg} \cdot \mathrm{kg}^{-1}$ in $42 \mathrm{~m}$ depth blow ground surface at $\mathrm{C} 1$ where coking wastewaters and oils produced during deep processing of tar and gas purification in the past. To our best knowledge, the site had the deepest unsaturated zone pollution of PAHs ever reported. Coking wastewaters contain high concentrations of LM-PAHs in aqueous phase and HM-PAHs adsorbed onto the suspended particles [35]. Chemical-recovery of tar produces oils and other aqueous by-products contain considerable amounts of LM-PAHs. In China, seepage from pools, oil tanks and pipelines were common due to backward technology and lack of environmental awareness in the past. It could cause deeper unsaturated zone pollution than infiltration of other sources under rainfall leaching condition.
Common to studies about PAHs distribution and migration in soils are just considering single pollutant. Due to strong hydrophobicity and high affinity for organic matter, it is difficult for PAHs to migrate downward at the profile in the case. A group of contaminants such as BTEX, phenols and cyanide always exist in coking or manufactured gas plant soils $[16,36]$. The multiple organic contaminants could affect one another with regard to dissolution and transport. For instance, the solubility of naphthalene in pure benzene is $33 \mathrm{~g} / 100 \mathrm{~g}$ [37]. Benzene could work as the co-solvent to improve PAHs migration capacity due to its lower octanol-water distribution coefficient. Russold et al. [38] suggested the solubility and transport of PAHs emanating with sufficient mobility could be significantly influenced upon benzene phase in groundwater. As a common coking by-product, phenol also could promote the solubility of PAHs in aqueous phase [39]. Humel et al. [40] found passive dosing of toluene induced an increase in the fraction of accessible PAHs but also enhanced the release rate of PAHs from soil through competitive adsorption, in particular, with more than 4-ring. This study also tested BTEX concentrations in unsaturated zone sampled at $\mathrm{Cl}$ and 
Table 3. Concentrations of $\Sigma 16 \mathrm{PAHs}$ and BTEX in unsaturated zone at two profiles.

\begin{tabular}{|c|c|c|c|c|c|c|}
\hline \multirow{2}{*}{ Location } & \multirow{2}{*}{$\begin{array}{c}\text { Depth } \\
\text { (m) }\end{array}$} & \multicolumn{5}{|c|}{ Concentration $\left(\mathrm{mg} \cdot \mathrm{kg}^{-1}\right)$} \\
\hline & & $\Sigma 16$ PAHs & Benzene & Toluene & Ethylbenzene & Xylene \\
\hline \multirow{6}{*}{$\mathrm{C} 1$} & 2.5 & 5927.30 & 2.10 & 51.90 & 53.70 & 414.00 \\
\hline & 4.6 & 1918.34 & 0.40 & 5.60 & 9.91 & 60.20 \\
\hline & 8.0 & 1114.46 & 0.40 & 7.52 & 22.80 & 111.00 \\
\hline & 24.1 & 1374.57 & 83.00 & 242.00 & 41.10 & 162.20 \\
\hline & 31.1 & 1907.37 & 36.30 & 142.00 & 23.63 & 122.70 \\
\hline & 42.0 & 65.27 & N.D. & N.D. & N.D. & N.D. \\
\hline \multirow{8}{*}{$\mathrm{C} 3$} & 0.4 & 638.63 & 10.40 & 8.89 & 0.25 & 10.17 \\
\hline & 2.5 & 243.55 & 13.80 & 14.40 & 0.44 & 21.63 \\
\hline & 4.0 & 6.42 & 20.90 & 6.53 & 0.12 & 2.45 \\
\hline & 4.7 & 847.27 & 47.80 & 17.70 & 0.34 & 2.14 \\
\hline & 9.0 & 8.90 & N.D. & N.D. & N.D. & N.D. \\
\hline & 14.2 & 0.50 & N.D. & N.D. & N.D. & N.D. \\
\hline & 25.2 & N.D. & N.D. & N.D. & N.D. & N.D. \\
\hline & 30.0 & 3.71 & N.D. & N.D. & N.D. & N.D. \\
\hline
\end{tabular}

N.D.: Not Detected

C3 (Table 3). It is obvious that PAHs and BTEX existed together at the profiles. BTEX were not detectable in more than $30 \mathrm{~m}$ depth probably caused by fluctuation of groundwater in which benzene phase was found. Groundwater depth was about $30 \mathrm{~m}$ and the minimum depth even approached $10 \mathrm{~m}$ in 1990s according to historical monitoring data of the region. Collecting samples in less than $10 \mathrm{~m}$ depth from the two profiles which were unaffected by groundwater certainly, strong linear correlation existed between $\mathrm{P}$ PAHs versus BTEX concentrations $(\mathrm{r}=0.969, \mathrm{n}=8)$. It is reasonable to believe that BTEX from seepage migrated together with PAHs in unsaturated zone by partitioning into the benzene phase. Furthermore, hydraulic conductivity in the gravel and pebble layer ranging from $3.8 \times 10^{-4}$ to $1.2 \times 10^{-1} \mathrm{~cm} \cdot \mathrm{s}^{-1}$ and sources intensity also play a critical role in promoting PAHs migration.

\section{Compositional Profiles of PAHs in Soils of Different Workshops}

High concentrations of PAHs have toxic effects on biomass, slowing or preventing biological degradation of PAHs [41]. The maximum concentrations of $\Sigma$ PAHs in different workshops could indicate initial compositions of the sources (Fig. 5). In the SP, BP, IM and SM sites, Fla, BbF, Pyr, Phe, Chry and BaA predominated in the 16 priority PAHs, the mean proportions of individual PAHs in the total (normalize fraction) were 15.1\%, $12.9 \%, 12.1 \%, 9.3 \%, 9.1 \%$ and $8.5 \%$ respectively. 4-ring PAHs was the dominant compound and contributed $37.3-49.5 \%$ to the total PAHs. Iron and steel industrial sites were susceptible to medium or high molecular weight PAHs because of (1) high-temperature pyrogenic sources were most likely responsible for the heavy PAH contamination [5]. Combustion temperature could exceed $1000^{\circ} \mathrm{C}$ during sintering, smelting and other processes and (2) due to their low vapor pressures, HM-PAHs exists mainly adsorbed to airborne particulate matter, such as fly ash and soot, while four or fewer rings occur both in the vapor phase and adsorb to particles [4, 42]. It is easier to deposit to the soil through wet and dry deposition for MM-PAHs and HMPAHs near sources, while gaseous LM-PAHs could be transported to remote areas [43].

Different from other workshops, PAHs in the CP and CS soils were dominated by LM-PAHs which contributed $49.5-50.3 \%$ to the total 16 PAHs. The two most abundant PAHs were Nap and Phe. Different sources in coking plants play distinguishing roles in compositions of individual PAHs in soils. Pyrolysis of coal in coke oven could generate exhaust gas, the soils affected by dry or wet deposition processes were susceptible to heavier compounds. While the toxic byproducts and contaminants in process of carbonization and refining were dominated in Nap, Ace, Flu, Phe and other LM-PAHs. For instance, Nap made up $42.6 \%$ of the total 16 PAHs mass in residual tar sampled from an abandoned tar pipeline in the CP. Coal tar, coking wastewater, crude gas, oils (naphthalene oil, phenol oil, anthracene oil, etc.) and other chemical materials through spill, leakage and discharge could lead to high levels of LM-PAHs in soil. It is apparent that the latter effect became the major contributor in 


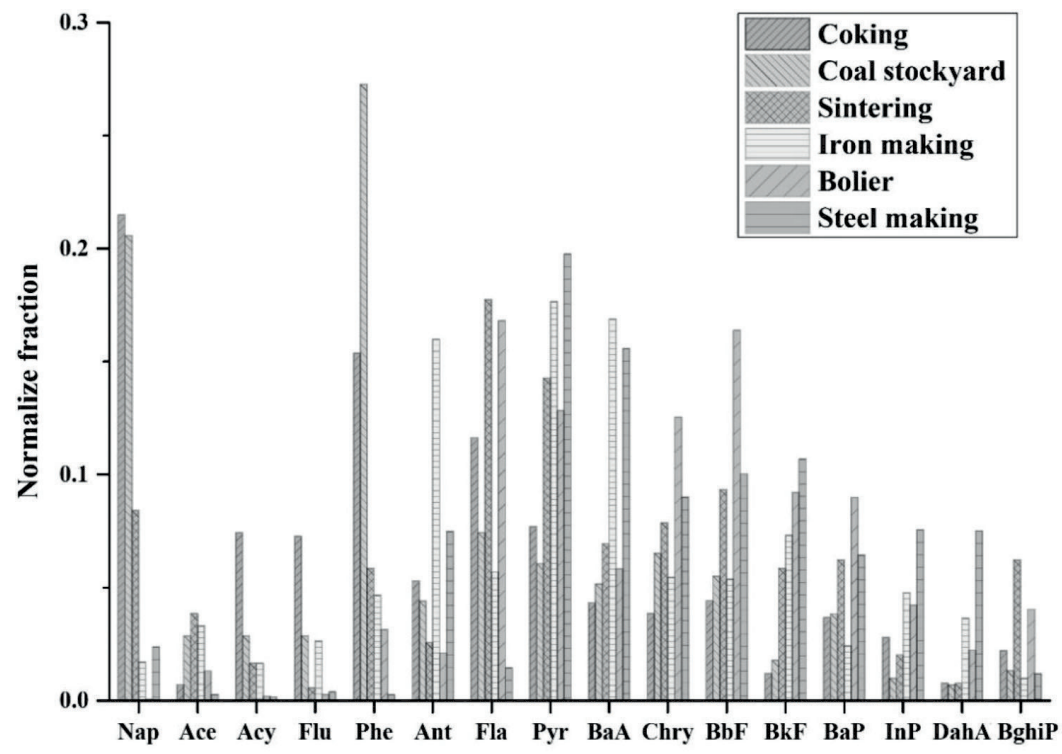

Fig. 5. Comparison of normalized composition profiles of PAHs in different workshops.
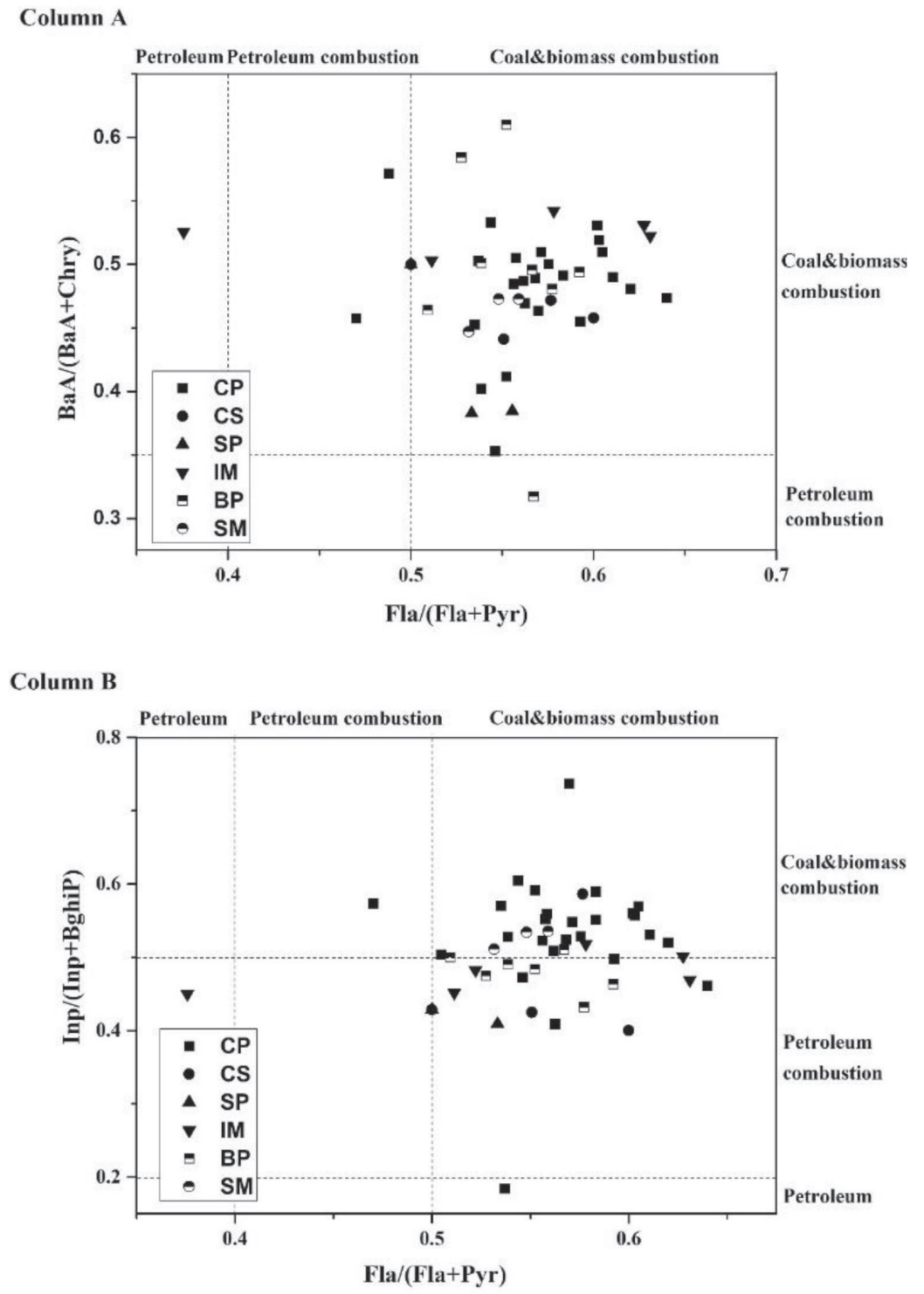

Fig. 6. Cross plots for the isomeric ratios of $\mathrm{BaA} /(\mathrm{BaA}+\mathrm{Chry}), \mathrm{InP} /(\mathrm{InP}+\mathrm{BghiP})$ and $\mathrm{Fla} /(\mathrm{Fla}+\mathrm{Pyr})$ in unsaturated zone. 


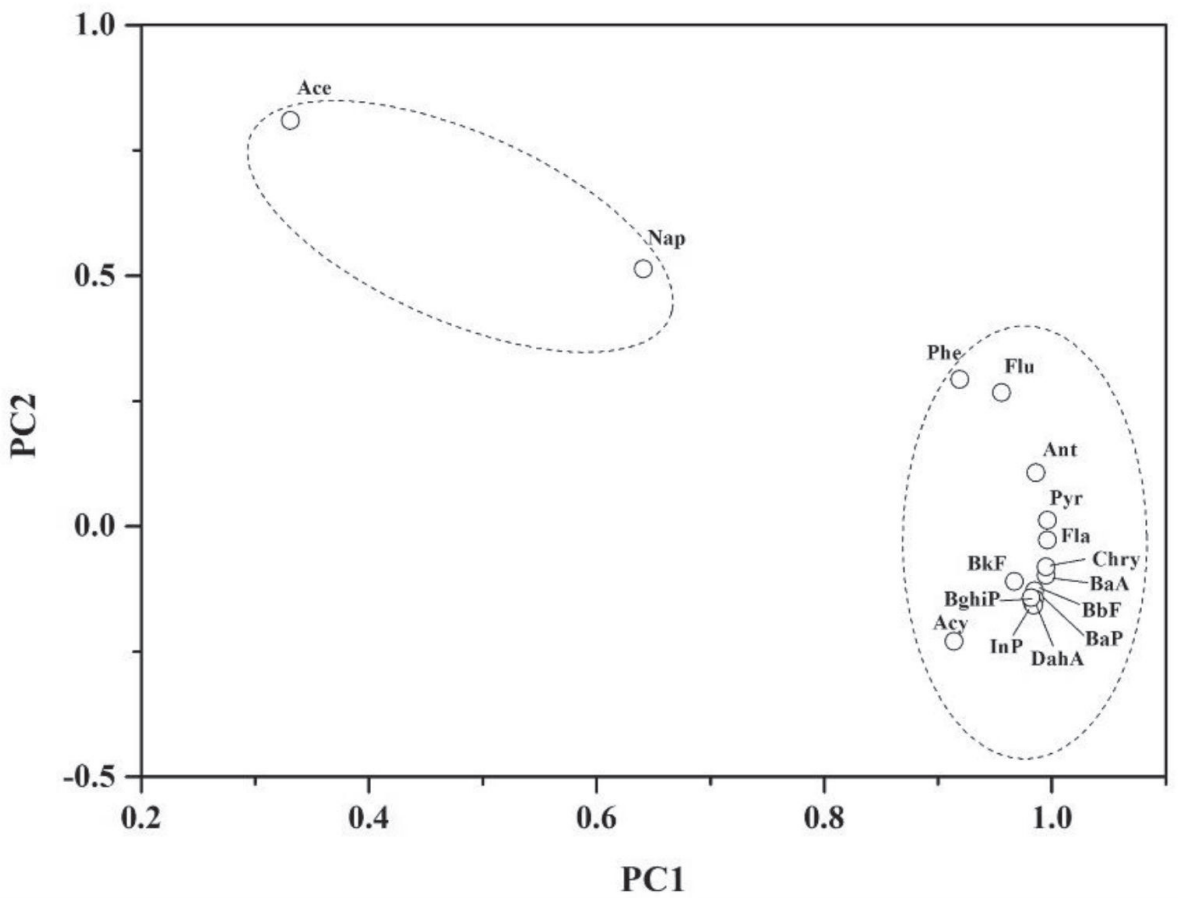

Fig. 7. PCA loading plot for 16 individual PAHs based on maximum values of $\Sigma$ PAHs at all sample sites.

the CP site. Historically, the CS site had not taken measures for seepage prevention and Nap, Phe dominate in the total PAHs of raw coal particles [44], leachate from rain eluviation and coal particles migrated into soil, which caused LM-PAHs pollution. Furthermore, the CS site located between coke oven and refining workshop, it was obvious that the site had been affected by the CP via winds (See Fig. 2).

\section{Source Identification}

\section{Isomeric Ratios of PAHs}

Isomeric ratios such as $\mathrm{Fla} /(\mathrm{Fla}+\mathrm{Pyr}), \mathrm{BaA} /(\mathrm{BaA}$ + Chry), and $\mathrm{InP} /(\mathrm{InP}+\mathrm{BghiP})$ have been widely used to distinguish environmental sources of PAHs. The identification for origin sources was performed according to the judgement summarized by Yunker et al. [45-46]. Fig. 6 showed diagnostic ratios of PAHs of all samples. According to ratios of $\mathrm{BaA} /(\mathrm{BaA}+\mathrm{Chry})$ and Fla/(Pyr + Fla), it suggested the dominant sources of PAHs in soils were coal and biomass combustion. Ratios of $\mathrm{InP} /(\mathrm{InP}+\mathrm{BghiP})$ indicated that petroleum combustion also contributed to the PAHs amount. As the energy-intensive industry, iron and steel enterprises heavily rely on coal in the manufacturing steps of production. In China, steel enterprises consumed 452 million tons of standard coal in 2018, made up approximately $16.5 \%$ of the total national consumption. Coal combustion has been the primary source of PAHs. Due to the transport of vehicles and the use of fuelfired boilers in the past, petroleum combustion sources existed in part of the field. Rachwał et al. [13] suggested that ratios of $\mathrm{IcdP} /(\mathrm{IcdP}+\mathrm{BghiP})$ varying from 0.4 to
0.5 and Flt/(Flt + Pyr) between 0.55 and 0.75 could be indicators of PAH contamination from coke production, whereas most isomeric ratios from different workshops were in accordance with the intervals. It is hardly possible to distinguish PAHs derived from different processes by isomeric ratios.

\section{Principal Component Analysis (PCA)}

Isomeric ratios of PAHs could not always identify the sources of PAHs pollution accurately [47], multivariate statistical analysis need to apply to further determination. As shown in Fig. 7, the first two principal components (PC) accounted for $94.4 \%$ of total variance and in line with the previous observations in urban soils of Beijing [20]. PC1 explained $86.5 \%$ of the total variance, with high loadings of all individual PAHs except Nap and Ace, and scores of HM-PAHs generally were higher than MM-PAHs. PC1 indicated pyrogenic source, InP and BghiP are related to traffic emission $[10,48]$, the others are considered as markers of coal and biomass combustion. PC2 explained $7.9 \%$ of the total variance, with high loadings of volatile PAHs, including Nap (0.50) and Ace (0.81) which are used to originate from coke oven emission [49]. PC2 reflected main sources from crude gas, coal tar, wastewater, oils and other chemical materials during the coking processes.

\section{Ecological Toxicity Assessment}

The most popular and widely accepted method for identification of toxicity of PAH in soil is toxic equivalency factor (TEF) [43]. The total toxicity 
Table 4. Toxic equivalent concentration $\left(\mathrm{BaP}_{\mathrm{eq}}\right)\left(\mathrm{mg} \cdot \mathrm{kg}^{-1}\right)$ of individuals $\mathrm{PAH}$ and soils from the different workshops.

\begin{tabular}{|c|c|c|c|c|c|c|c|c|}
\hline PAHs & TEFs & CP & CS & SP & IM & BP & SM & All the workshops \\
\hline Nap & 0.001 & 0.542 & 0.001 & 0.000 & 0.002 & 0.000 & 0.000 & 0.546 \\
\hline Ace & 0.001 & 0.123 & 0.000 & 0.000 & 0.002 & 0.000 & 0.000 & 0.126 \\
\hline Acy & 0.001 & 0.082 & 0.000 & 0.000 & 0.002 & 0.000 & 0.000 & 0.085 \\
\hline Flu & 0.001 & 0.178 & 0.000 & 0.000 & 0.003 & 0.000 & 0.000 & 0.182 \\
\hline Phe & 0.001 & 0.395 & 0.002 & 0.001 & 0.012 & 0.003 & 0.002 & 0.415 \\
\hline Ant & 0.01 & 1.202 & 0.004 & 0.003 & 0.042 & 0.014 & 0.004 & 1.268 \\
\hline Fla & 0.001 & 0.236 & 0.001 & 0.001 & 0.019 & 0.008 & 0.005 & 0.270 \\
\hline Pyr & 0.001 & 0.161 & 0.001 & 0.001 & 0.015 & 0.007 & 0.004 & 0.189 \\
\hline BaA & 0.1 & 8.129 & 0.051 & 0.097 & 0.749 & 0.428 & 0.231 & 9.685 \\
\hline Chry & 0.01 & 0.775 & 0.006 & 0.012 & 0.069 & 0.055 & 0.026 & 0.943 \\
\hline BbF & 0.1 & 8.849 & 0.070 & 0.180 & 1.149 & 0.798 & 0.278 & 11.323 \\
\hline BkF & 0.1 & 2.721 & 0.022 & 0.060 & 0.336 & 0.326 & 0.184 & 3.649 \\
\hline BaP & 1 & 69.216 & 0.420 & 1.117 & 6.751 & 3.646 & 2.011 & 83.160 \\
\hline InP & 0.1 & 4.645 & 0.021 & 0.048 & 0.432 & 0.219 & 0.197 & 5.561 \\
\hline DahA & 1 & 12.921 & 0.097 & 0.207 & 1.250 & 0.780 & 0.373 & 15.627 \\
\hline BghiP & 0.01 & 0.375 & 0.003 & 0.007 & 0.049 & 0.022 & 0.017 & 0.473 \\
\hline$\Sigma_{16}$ PAHs & & 110.550 & 0.698 & 1.734 & 10.883 & 6.306 & 3.332 & \\
\hline
\end{tabular}

equivalency concentrations $\left(\mathrm{BaP}_{\text {eq }}\right)$ of individuals $\mathrm{PAH}$ and the different workshops were calculated using the following equation:

$$
\mathrm{TEQ}_{\mathrm{Bap}}=\Sigma\left(\mathrm{C}_{\mathrm{i}} \times \mathrm{TEF}_{\mathrm{i}}\right)
$$

...where $\mathrm{C}_{\mathrm{i}}$ is the concentration of individual carcinogenic $\mathrm{PAH}$ and $\mathrm{TEF}_{\mathrm{i}}$ is the corresponding toxic equivalency factor. TEFs for the 16 PAHs were calculated according to Tsai et al. [50].

The calculated TEQ of the CP site was found highest in all the workshops (Table 4), and it accounted for $62.3 \%$ of the total TEQ indicating the highest carcinogenic potential in the soil. It is widely considered coking sites have been a major environmental concern due to tar oil contamination and the difficulty of reaching remediation end-points [15]. The calculated TEQ of BaP alone accounted for $57.8-64.4 \%$ of all the 16 PAHs, followed by DahA (11.2-14.8\%), BbF $(8.0-12.6 \%)$ in the different workshops. BaP was considered as the predominant carcinogenic contributor since the TEQ was even 5 times higher than the second most dominant PAH (DahA). LM-PAHs and MM-PAHs played a dominant role in the field and were regarded as the typical pollutants in terms of concentration, whereas such PAHs just accounted for about $10.3 \%$ of the total TEQ because of their relatively low TEF values. It should be paid more attention to HM-PAHs, especially for $\mathrm{BaP}$ when conducting environmental monitoring and risk assessment in iron and steel industrial field.

\section{Conclusion}

Maximum $\Sigma$ PAHs concentrations in soil of the different workshops ranged from 17.50 to 11266.80 $\mathrm{mg} \cdot \mathrm{kg}^{-1}$. Almost all the samples were heavily contaminated and the $\mathrm{CP}$ site was polluted most severely due to mixing with coal tar, tar oils in soil. The different levels and spatial distribution in soils were strongly associated with discharge ways and combustion condition during utilization of metallurgical coal. The lithology played the major role in vertical distribution of PAHs and gravel and pebble layer became the preferential flow paths, while embedded sand or silt lens existed as the pooling layers and penetrating barriers at the profiles of the $\mathrm{CP}$ site. The competitive adsorption and co-solvent effect from BTEX contributed to the vertical transport of PAHs in unsaturated zone. Nap and Phe were the most abundant compounds and LMPAHs dominated in the CP and CS sites. While 4-ring PAHs was the dominant compound and contributed $37.3-49.5 \%$ to the total mass in the other workshops. Coal combustion was the primary source of PAHs and petroleum combustion also existed in the field. LMPAHs and MM-PAHs played a dominant role in soils owning to their high concentration, whereas HM-PAHs accounted $89.7 \%$ for the calculated TEQ of the total PAHs and $\mathrm{BaP}$ was the most toxic pollutant due to the higher TEF values. 


\section{Conflict of Interest}

The authors declare no conflict of interest.

\section{References}

1. ZHANG P., CHEN Y. Polycyclic aromatic hydrocarbons contamination in surface soil of China: a review. Sci. Total Environ. 605, 1011, 2017.

2. CHEN Y.N., SUN C.Y., ZHANG J.Q., ZHANG F. Assessing 16 polycyclic aromatic hydrocarbons (PAHs) in river basin water and sediment regarding spatial-temporal dstribution, partitioning, and ecological risks. Pol. J. Environ. Stud. 27 (2), 578, 2018.

3. SHEN H.Z., HUANG Y., WANG R., Zhu D., Li W., SHEN G.F., WANG B., ZHANG Y.Y., CHEN Y.Y., LU Y., CHEN H., Li T.C., SUN K., LI B.G., LIU W.X., LIU J.F., Tao S. Global atmospheric emissions of polycyclic aromatic hydrocarbons from 1960 to 2008 and future predictions. Environ. Sci. Technol. 47, 1011, 2013.

4. YANG H.H., LAI S.O., HSIEH L.T., HSUEH H.J., CHI T.W. Profiles of PAH emission from steel and iron industries. Chemosphere. 48 (10), 1061, 2002.

5. DUAN Y.H., SHEN G.F., TAO S., HONG J.P., CHEN Y.C., XUE M., LI T.C., SU S., SHEN H.G., FU X.F., MENG Q.C., GUO Y.Y., GAO X., ZHU T.Y., LUO L., ZHENG Y. Chemical profiles of PM emitted from the iron and steel industry in northern China. Atmos. Environ. 150, 187, 2016.

6. LIN Y.C., LEE W.J., CHEN S.J., CHANG-CHIEN G.P., TSAI P.J. Characterization of PAHs exposure in workplace atmospheres of a sinter plant and health-risk assessment for sintering workers. J. Hazard. Mater. 158 (2-3), 636, 2008.

7. KHAPARDE V.V., BHANARKAR A.D., MAJUMDAR D., Rao C.V.C. Characterization of polycyclic aromatic hydrocarbons in fugitive $\mathrm{PM}_{10}$ emissions from an integrated iron and steel plant. Sci. Total Environ. 562, 155, 2016.

8. WANG C.H., WU S.H., ZHOU S.L., WANG H., LI B.J., CHEN H., YU Y.N., SHI Y.X. Polycyclic aromatic hydrocarbons in soils from urban to rural areas in Nanjing: concentration, source, spatial distribution, and potential human health risk. Sci. Total Environ. 527, 375, 2015.

9. WANG D., MA J., LI H., ZHANG X.C. Concentration and potential ecological risk of PAHs in different layers of soil in the petroleum-contaminated areas of the loess plateau, China. Int. J. Environ. Res. Public Health 15, 1, 2018.

10. AGARWAL T., KHILLARE P.S., SHRIDHAR V., RAY S. Pattern, sources and toxic potential of PAHs in the agricultural soils of Delhi, India. J. Hazard. Mater. 163, 1033, 2009.

11. BRUMMELEN T.C.V., VERWEIJ R.A., WEDZINGA S.A., GESTEL C.A.M.V. Enrichment of polycyclic aromatic hydrocarbons in forest soils near a blast furnace plant. Chemosphere. 32(2), 293, 1996.

12. ZHANG W.H., WEI C.H., FENG C.H., YU Z., REN M., YAN B., PENG P.G., FU J.M. Distribution and health-risk of polycyclic aromatic hydrocarbons in soils at a coking plant. J. Environ. Monit. 13 (12), 3429, 2011.

13. RACHWAŁ M., MAGIERA T., WAWER M. Coke industry and steel metallurgy as the source of soil contamination by technogenic magnetic particles, heavy metals and polycyclic aromatic hydrocarbons. Chemosphere. 138, 863, 2015.

14. VULAVA V.M., MCKAY L.D., DRIESE S.G., MENN F.M., SAYLER G.S. Distribution and transport of coal tarderived PAHs in fine-grained residuum. Chemosphere. 68 (3), 554, 2007.

15. TRELlU C., MiLTNER A., GALlO R., HUGUENOT D., VAN HULLEBUSCH E.D., ESPOSITO G., OTURAN M.A., KÄSTNER M. Characteristics of PAH tar oil contaminated soils-black particles, resins and implications for treatment strategies. J. Hazard. Mater. 327, 206, 2017.

16. TOTSCHE, K.U., KÖGEL-KNABNER I., HAAS B., GEISEN S., SCHEIBKE R. Preferential flow and aging of NAPL in the unsaturated soil zone of a hazardous waste site: implications for contaminant transport. J. Plant Nutr. Soil Sci. 166 (1), 102, 2003.

17. ABRAMS R.H., LOAGUE K. Legacies from three former manufactured-gas plants: impacts on groundwater quality. Hydrogeol. J. 8 (6), 594, 2000.

18. LI H.L., CHEN J.J., WU W., PIAO X.S. Distribution of polycyclic aromatic hydrocarbons in different size fractions of soil from a coke oven plant and its relationship to organic carbon content. J. Hazard. Mater. 176 (1-3), 729, 2010.

19. JIA H.Z., ZHAO S., NULAJI G., TAO K.L., WANG F., SHARMA V.K., WANG C.Y. Environmentally persistent free radicals in soils of past coking sites: distribution and stabilization. Environ. Sci. Technol. 51 (11), 6000, 2017.

20. PENG C., CHEN W.P., LIAO X.L., WANG M., OUYANG Z.Y., JIAO W.T., BAI Y. Polycyclic aromatic hydrocarbons in urban soils of Beijing: status, sources, distribution and potential risk. Environ. Pollut. 159 (3), 802, 2011.

21. MALISZEWSKA-KORDYBACH B. Polycyclic aromatic hydrocarbons in agricultural soils in Poland: preliminary proposals for criteria to evaluate the level of soil contamination. Appl. Geochem. 11 (1-2), 121, 1996.

22. GAO B., FENG Q.Y., ZHOU L., HU H.W., ALAM E. Distributions of polycyclic aromatic hydrocarbons in coal in China. Pol. J. Environ. Stud. 28 (3), 1665, 2019.

23. AHN S., WERNER D., LUTHY R.G. Physicochemical characterization of coke-plant soil for the assessment of polycyclic aromatic hydrocarbon availability and the feasibility of phytoremediation. Environ. Toxicol. Chem. 24, 2185, 2005.

24. JONKER M.T.O., KOELMANS A.A. Sorption of polycyclic aromatic hydrocarbons and polychlorinated biphenyls to soot and soot-like materials in the aqueous environment: mechanistic considerations. Environ. Sci. Technol. 36 (17), 3725, 2002.

25. YANG Y., LIGOUIS B., PIES C., GRATHWOHL P., HOFMANN T. Occurrence of coal and coal-derived particle-bound polycyclic aromatic hydrocarbons (PAHs) in a river floodplain soil. Environ. Pollut. 151 (1), 121, 2008.

26. CHEN C.F., CHEN C.W., JU Y.R., DONG C.D. Vertical profile, source apportionment, and toxicity of PAHs in sediment cores of a wharf near the coal-based steel refining industrial zone in Kaohsiung, Taiwan. Environ. Sci. Pollut. Res. 23 (5), 4786, 2015.

27. JIAO H.H., BIAN G.P., CHEN X., WANG S.L., ZHUANG X.Y., BAI Z.H. Distribution, sources, and potential risk of polycyclic aromatic hydrocarbons in soils from an industrial district in Shanxi, China. Environ. Sci. Pollut. Res. 24 (13), 12243, 2017. 
28. KWON H.O., CHOI S.D. Polycyclic aromatic hydrocarbons (PAHs) in soils from a multi-industrial city, South Korea. Sci. Total Environ. 470-471, 1494, 2014.

29. FALAY O.Y., TUAN G., ALTIOK H., KARA M., DUMANOGLU Y., BAYRAM A., TOLUNAY D., ELBIR T., ODABASI M. Spatial variation of polycyclic aromatic hydrocarbons (PAHs) in air, soil and tree components in Iskenderun Industrial Region, Turkey. International Journal of Chemical, Environmental \& Biological Sciences. 1(2), 263, 2013.

30. JIA J.P., BI C.J., GUO X., WANG X.P., ZHOU X.X., CHEN Z.L. Characteristics, identification, and potential risk of polycyclic aromatic hydrocarbons in road dusts and agricultural soils from industrial sites in Shanghai, China. Environ. Sci. Pollut. Res. 24 (1), 605, 2017.

31. ZHU L.Z., CHEN Y.Y., ZHOU R.B. Distribution of polycyclic aromatic hydrocarbons in water, sediment and soil in drinking water resource of Zhejiang Province, China. J. Hazard. Mater. 150 (2), 308, 2008.

32. TOTSCHE K.U., JANN S., KÖGEL-KNABNER I. Release of polycyclic aromatic hydrocarbons, dissolved organic carbon, and suspended matter from disturbed NAPL-contaminated gravelly soil material. Vadose Zone J. 5 (1), 469, 2006.

33. ABDEL-SHAFY H.I., MANSOUR M.S.M. A review on polycyclic aromatic hydrocarbons: source, environmental impact, effect on human health and remediation. Egyptian Journal of Petroleum, 25, 107, 2016.

34. ILLANGASEKARE T.H., RAMSEY J.L., JENSEN K.H., BUTTS M.B. Experimental study of movement and distribution of dense organic contaminants in heterogeneous aquifers. J. Contam. Hydrol. 20 (1-2), 1, 1995.

35. ZHANG W.H., WEI C.H., CHAI X.S., HE J.J., CAI Y., REN M., YAN B., PENG P.A., FU J.M. The behaviors and fate of polycyclic aromatic hydrocarbons (PAHs) in a coking wastewater treatment plant. Chemosphere. 88 (2), 174, 2012.

36. WEIGAND H., TOTSCHE K.U., HUWE B., KÖGELKNABNER I. PAH mobility in contaminated industrial soils: a Markov chain approach to the spatial variability of soil properties and PAH levels. Geoderma 102 (3), 371, 2001.

37. DEAN J.A. Lange's Handbook of Chemistry, 14th ed. McGraw-Hill, New York. 1997.

38. RUSSOLD S., SCHIRMER M., PIEPENBRINK M., SCHIRMER K. Modeling the impact of a benzene source zone on the transport behavior of PAHs in groundwater. Environ. Sci. Technol. 40 (11), 3565, 2006.

39. KONG Q.P., WU H.Z., LIU L., ZHANG F.Z., PREIS S., ZHU S., WEI C.H. Solubilization of polycyclic aromatic hydrocarbons (PAHs) with phenol in coking wastewater treatment system: interaction and engineering significance. Sci. Total Environ. 628-629, 467, 2018.
40. HUMEL S., SCHMIDT S.N., SUMETZBERGERHASINGER M., MAYER P., LOIBNER A.P. Enhanced accessibility of PAHs and heterocyclic PAHs in industrially contaminated soil after passive dosing of a competitive sorbate. Environ. Sci. Technol. 51 (14), 8017, 2017.

41. MAHMOUDI N., SLATER G.F., JUHASZ A.L. Assessing limitations for PAH biodegradation in long-term contaminated soils using bioaccessibility assays. Water, Air, Soil Pollut. 224 (2), 1411, 2013.

42. CHEN B.L., XUAN X.D., ZHU L.Z., WANG J., GAO Y.Z., YANG K., SHENG X.Y., LOU B.F. Distributions of polycyclic aromatic hydrocarbons in surface waters, sediments and soils of Hangzhou City, China. Water Res. 38 (16), 3558, 2004.

43. YADAV Y.C., DEVI N.L., QI S.H., DAN Y., ZHANG G. Environmental carcinogenic polycyclic aromatic hydrocarbons in soil from Himalayas, India: implications for spatial distribution, sources apportionment and risk assessment. Chemosphere. 144, 493, 2016.

44. ACHTEN C., CHENG S., STRAUB K.L., HOFMANN T. The lack of microbial degradation of polycyclic aromatic hydrocarbons from coal-rich soils. Environ. Pollut. 159 (2), 623, 2011.

45. YUNKER M.B., MACDONALD R.W., GOYETTE D., PATON D.W., FOWLER B.R., SULLIVAN D., JANICE B. Natural and anthropogenic inputs of hydrocarbons to the Strait of Georgia. Sci. Total Environ. 225 (3), 181, 1999.

46. YUNKER M.B., MACDONALD R.W., VINGAZAN R., MITCHELL R.H., GOYETTE D., STRACHAN S. PAHs in the Fraiser River basin: a critical appraisal of PAHs ratios as indicators of PAH source and composition. Org. Geochem. 33 (4), 489, 2002.

47. LAN J.C., SUN Y.C., XIAO S.Z., YUAN D.X. Polycyclic aromatic hydrocarbon contamination in a highly vulnerable underground river system in Chongqing, Southwest China. J. Geochem. Explor. 168, 65, 2016.

48. TONG R.P., YANG X.Y., SU H.R., PAN Y., ZHANG Q.Z., WANG J., LONG M. Levels, sources and probabilistic health risks of polycyclic aromatic hydrocarbons in the agricultural soils from sites neighboring suburban industries in shanghai. Sci. Total Environ. 616-617, 1365, 2017.

49. LIU J., LIU Y.J., LIU Z., ZHANG A.N., LIU Y. Source apportionment of soil PAHs and human health exposure risks quantification from sources: the Yulin National Energy and Chemical Industry Base, China as case study. Environ. Geochem. Health 41 (2), 617, 2018.

50. TSAI P.J., SHIH T.S., CHEN H.L., LEE W.J., LAI C.H., LIOU S.H. Assessing and predicting the exposures of polycyclic aromatic hydrocarbons (PAHs) and their carcinogenic potencies from vehicle engine exhausts to highway toll station workers. Atmos. Environ. 38 (2), 333, 2004. 